\title{
Stress and Job Performance of Secretaries in an Organization
}

\author{
Akasi Sunday Ebhodaghe ${ }^{1} \quad$ Popoola, Kofoworola Oyindamola ${ }^{2 *}$ \\ 1.Office Technology and Management Department, Federal Polytechnic Ede, Osun State, Nigeria \\ 2.Information Management Department, Lead City University Ibadan, Oyo State, Nigeria
}

\begin{abstract}
Stress can be said to be non-specific reaction of the body to the demand made on it by external or internal stimulus events called stressor. Stress as emotional process has psychological and physiological implications. Many professional secretaries experience conflicts because of office demands which is consuming most of their time, thereby neglecting their home duties to the background. Conflicts occur because the person wants to devote adequate attention to both family and office works. This research examines impact of stress on job performance of secretaries in an organization. The population of the study was 50 graduate secretaries in the employment of the Federal Polytechnic, Ede and Adeleke University, Ede both in Osun State. The instrument for data collection was questionnaire, which consisted of 4 research questions. Data collected to answer the research questions were analyze with frequency and percentages. From the data collected and analyzed, it was discovered that secretaries face a lot of stressful situations in the course of doing their jobs but that some were more stressful in their effect than others. The three most significant stressors identified were working Role ambiguity, work overload and unfair treatment. Recommendations were made that secretaries should clearly outline their numerous official and domestic functions daily and attend to them adequately. They should learn to put their emotions under control and manage their stress by practicing time and role management.
\end{abstract}

Keywords: Stress, Job performance, Secretaries, Organization

DOI: $10.7176 / \mathrm{EJBM} / 12-32-04$

Publication date: November $30^{\text {th }} 2020$

\section{Introduction}

The work of secretaries are stressful in nature since they are the head and eye of the organization. Sometimes secretaries feel depressed and discourages because of the work fully packed for them and there is inadequate time to tackle all these jobs, even at that, the manager will be shouting on them to hurry up, and as the secretary looks around and finds no help, stress arises(John, 2017). The roles and functions of the secretary are basic to the organization - this range from covering meetings, taking care of all office routine duties, keeping schedules in her boss's desk diaries for complete and effective job performance up to date and supervising sub-ordinates as well as keeping other general information in the office. In the organization, she is also important to the organization because of her ability to remain calm under extra-ordinary condition of work pressures and human demands.

\section{Statement of the Problem}

Stress comes as a result of over working oneself. Over work may emanate from the manager of an organization or the secretary herself. A situation where the manager fail to recruit more workers in the organization, this will generate stressful condition for the secretaries working with them which may lead to frustrations, tension and anxiety and as a result of this problem may occur. The secretary herself causes stress in her job, as a result of her inability to schedule her time according to her engagements. In view of the adverse effects of stress on the performance of the secretary, it becomes imperative to take a very keen look at the reasons for stress in work place, the effect of stress on the job performance of secretary and ways of improving the condition using empirical evidence.

\section{Research Questions}

The following research questions were raised to guide this research study.

1. What are the causes of stress on the secretary's performance?

2. To what extent does stress affect the job performance of the secretary?

3. How does stress affect the organizational goal?

4. What could be done to reduce or eliminate stress?

\section{Influence of Stress on Secretary's Job Performance}

There is significant inconsistency among researchers concerning the direct and indirect effects of stress. Direct stress effects are those incurred by the task load alone irrespective of any psychological stress that may also be generated. Accordingly, indirect stress effects are those that evolve out of psychological factors associated with the task load demands. There is a fine line that separates these two, and they can be indistinguishable at times. 
This fact has made their separation and measurement particularly difficult. However, while exposure to some level of stress may help individual performance, the long-term effects of stress on the individual tend to be negative, according to the majority of research looking at prolonged exposure to stress. One potential result of an extended exposure to a single or to multiple stressors is burnout, to include exhaustion, feelings of cynicism and detachment, a sense of ineffectiveness, and lack of accomplishment. It was argued that high and consistent exposure to stress can lead to burnout. High levels of stress can lead to emotional exhaustion, which has been shown to degrade organizational commitment and increase turnover intentions (Mathis \& Jackson, 2014)

According to Jamal, (2012), stress can also lead to physical problems, including cardiovascular disease, muscle pain, stomach and intestinal problems, decreased fertility, and reduced immune system strength. Longterm stress can also lead to feelings of anger, anxiety, fatigue, depression, and sleep problems. In the extreme, long-term exposure to high levels of stress or a single exposure to a very demanding event can lead to posttraumatic stress disorder, a psychiatric illness that can interfere with life functioning. Stress has a variety of symptoms, including nightmares, flashbacks, difficulty sleeping, and social isolation.

Although much of the research on the relationship between stress and functioning focuses on the negative performance effects of stress, not all stress is bad. In fact, emphasizes that stress is a necessary part of life and that it does not always involve negative consequences for the organism involved. In fact, at certain moderate levels, stress can actually improve individual performance. There is substantial research supporting the concept of "good stress."

It was argued that individual performance increases with stress and resulting arousal to an optimal point and then decreases as stress and stimulation increase beyond this optimum. Furthermore, it was opined that an inverted relationship does exist between stress and job performance in the industrial context. It was stated that performance is optimal when arousal is at moderate levels. When arousal is either too high or too low, performance declines.

According to Ali (2005), under conditions of stress, individual decision-making processes, perception, cognition, and judgment are all affected. For example, individuals may experience perceptual narrowing, reduced attention to peripheral stimuli, and increased task completion time. In group situations, stress may lead individuals to rely on the orders of their superiors. Group performance can also be affected by reduced communication effectiveness, concentrated authority, and poor judgment resulting from groupthink. While the general view of stress is that it has negative consequences, it is widely accepted that the relationship between stress and important outcome measures is more complicated. That is, moderate levels of stress are often associated with improved outcomes, while low and high levels of stress and arousal are linked to lowered outcomes.

Han (2009), suggests that performance for different types of secretary's operations could vary as a function of stress. For example, for certain operations, moderate levels of stress may contribute to improved outcomes (performance, job satisfaction, etc.). However, for other operations that have frequent and significant stressors, stress appears to have negative effects on secretary's outcomes, such as mental health (particularly in the long term). Organization planners may be able to use this information to their advantage by identifying and reducing stress in situations in which it has negative effects on judgment and decision-making and by maintaining moderate levels of stimulation where stress can be beneficial for outcomes. It also seems significant that it tends to be individual perception, judgment, and decision-making processes that are most affected by stress. As a result, organization's trainers and leaders should focus on developing these skills among junior personnel through training or other exercises.

According to Han, (2009), the following are the effects of stress on secretary's job performance in an organization:

* Stress affecting secretaries leads them to have bad performance in the discharge of their duties. Secretaries experience a lack of concentration. Stress can affect the ability to concentrate, and stress interferes with a secretary's ability to concentrate, Ironically stress Improves concentration for a short term because when secretaries are little stressed up they then to focus to try to get the issue in question which stresses them away but these concentrations doesn't last for long since they will have more work to do for their boss and others assignments to do which demand long-term concentrations rather than the short term.

* Furthermore, stress affect the productivity or the output of secretaries. When secretaries are stressed up they turn not to give their maximum best when doing when discharging their duties and as a result, it manifests in the outputs they bring which are clearly seen in the work they do. They do their work in a shabby manner not following the instructions giving the assignments in question. In the long term, it can even affect their plans for the future.

* Also, stress affects the initiative skills of secretaries. Most secretaries when stressed upturn to lack the ability to bring up new ideas to solve problems or issues, thus when secretaries are faced with some challenges which might be even so easy to solve because they are stressed up to refuse or are unable to rack their brains to find solutions to that problem. 
* Lastly, stress cause secretaries to be confused and also suffer from amnesia. All secretaries when stressed upturn to be sixes and sevens with the little-complicated issues. They easily have misunderstandings with what is to be done on the task given to them and don't know what to do. On the other hand, many of them also forget easily what have they know or have been told because their minds are burdened with the issues that are stressing them up. All these points impact of stress on secretaries, in the long run, cause them to perform poorly in an organization.

\section{Methodology}

Survey research method was used. The population of this study was 50 graduate secretaries, both male and female in the employment of the Federal Polytechnic, Ede, Osun State. The instrument for data collection was questionnaire. The structured questionnaire was administered personally by the researcher and collection was also made by him. To validate the instrument used for this study, the instrument was subjected to face and content validity by two experts to ensure that the questionnaire was capable of eliciting responses needed for the objectives of the study. Data collected were analyse using frequency count and percentages.

Results presentation and Analysis

Table 1: Research Question 1 - What are the causes of stress on the secretary's performance?

\begin{tabular}{|l|l|l|l|}
\hline Question Items & Responses & Frequency of responses & Percentage (\%) \\
\hline Work overload & Strongly agreed & 30 & $60 \%$ \\
& Agree & 10 & $20 \%$ \\
& Disagree & 5 & $10 \%$ \\
& Strongly Disagree & 5 & $10 \%$ \\
& Total & $\mathbf{5 0 \%}$ & $\mathbf{1 0 0} \%$ \\
\hline Role ambiguity & Strongly agreed & 20 & $40 \%$ \\
& Agree & 22 & $44 \%$ \\
& Disagree & 5 & $10 \%$ \\
& Strongly Disagree & 3 & $6 \%$ \\
& Total & $\mathbf{5 0 \%}$ & $\mathbf{1 0 0 \%}$ \\
\hline Lack of concentration & Strongly agreed & 30 & $60 \%$ \\
& Agree & 10 & $20 \%$ \\
& Disagree & 5 & $10 \%$ \\
& Strongly Disagree & 5 & $10 \%$ \\
& Total & $\mathbf{5 0 \%}$ & $\mathbf{1 0 0 \%}$ \\
\hline Lack of job specification & Strongly agreed & 31 & $62 \%$ \\
& Agree & 11 & $22 \%$ \\
& Disagree & 6 & $12 \%$ \\
& Strongly Disagree & 2 & $4 \%$ \\
& Total & $\mathbf{5 0 \%}$ & $\mathbf{1 0 0} \%$ \\
\hline Lack of equipment and material & Strongly agreed & 28 & $56 \%$ \\
needed for effective job performance & Agree & 10 & $20 \%$ \\
& Disagree & 7 & $14 \%$ \\
& Strongly Disagree & 5 & $10 \%$ \\
& Total & $\mathbf{1 0 0 \%}$ \\
\hline
\end{tabular}

Source: Field Survey 2020 
Table 2: Research Question 2 - To what extent does stress affect the job performance of secretary?

\begin{tabular}{|c|c|c|c|}
\hline Question Items & Responses & Frequency of responses & Percentage (\%) \\
\hline \multirow[t]{5}{*}{ It reduced concentration } & Very High Extent & 31 & $62 \%$ \\
\hline & High Extent & 10 & $20 \%$ \\
\hline & Low Extent & 4 & $8 \%$ \\
\hline & Very Low Extent & & $10 \%$ \\
\hline & Total & $50 \%$ & $100 \%$ \\
\hline \multirow{5}{*}{$\begin{array}{l}\text { It leads to reduction in productivity of } \\
\text { secretaries }\end{array}$} & Very High Extent & 30 & $60 \%$ \\
\hline & High Extent & 10 & $20 \%$ \\
\hline & Low Extent & 5 & $10 \%$ \\
\hline & Very Low Extent & & $10 \%$ \\
\hline & Total & $50 \%$ & $100 \%$ \\
\hline \multirow{5}{*}{$\begin{array}{l}\text { It leads to rise in inferiority complex } \\
\text { among secretaries }\end{array}$} & Very High Extent & 10 & $20 \%$ \\
\hline & High Extent & 5 & $10 \%$ \\
\hline & Low Extent & 25 & $50 \%$ \\
\hline & Very Low Extent & 10 & $20 \%$ \\
\hline & Total & $50 \%$ & $100 \%$ \\
\hline \multirow[t]{5}{*}{ Its leads to job dissatisfaction } & Very High Extent & 31 & $62 \%$ \\
\hline & High Extent & 11 & $22 \%$ \\
\hline & Low Extent & 6 & $12 \%$ \\
\hline & Very Low Extent & & $4 \%$ \\
\hline & Total & $50 \%$ & $100 \%$ \\
\hline \multirow[t]{5}{*}{ It leads to unnecessary aggression } & Very High Extent & 20 & $40 \%$ \\
\hline & High Extent & 10 & $20 \%$ \\
\hline & Low Extent & 10 & $20 \%$ \\
\hline & Very Low Extent & 10 & $20 \%$ \\
\hline & Total & $50 \%$ & $100 \%$ \\
\hline
\end{tabular}

Source: Field Survey 2020

Table 3: Research Question 3 - How does stress affect the organizational goals?

\begin{tabular}{|l|l|l|l|}
\hline Question Items & Responses & Frequency of responses & Percentage (\%) \\
\hline It lead to low morale & Strongly agreed & 40 & $80 \%$ \\
& Agree & 5 & $10 \%$ \\
& Disagree & 3 & $6 \%$ \\
& Strongly Disagree & 2 & $4 \%$ \\
& Total & $\mathbf{5 0 \%}$ & $\mathbf{1 0 0 \%}$ \\
\hline It causes poor working relationship & Strongly agreed & 10 & $20 \%$ \\
among workers & Agree & 5 & $10 \%$ \\
& Disagree & 25 & $50 \%$ \\
& Strongly Disagree & 10 & $20 \%$ \\
& Total & $\mathbf{5 0 \%}$ & $\mathbf{1 0 0 \%}$ \\
\hline It reduces productivity & Strongly agreed & 31 & $62 \%$ \\
& Agree & 11 & $22 \%$ \\
& Disagree & 6 & $12 \%$ \\
& Strongly Disagree & 2 & $4 \%$ \\
& Total & $\mathbf{5 0} \%$ & $60 \%$ \\
\hline It increases rate of absentees & Strongly agreed & 30 & $14 \%$ \\
& Agree & 7 & $20 \%$ \\
\hline It leads to high rate of employees & Disagree & 10 & $6 \%$ \\
turnover & Strongly Disagree & 3 & $\mathbf{1 0 0 \%}$ \\
& Total & $\mathbf{5 0 \%}$ & $40 \%$ \\
& Agree & 20 & $20 \%$ \\
& Disagree & 10 & $20 \%$ \\
& Strongly Disagree & 10 & $\mathbf{2 0 \%}$ \\
\hline & Total & $\mathbf{1 0 0 \%}$ \\
\hline
\end{tabular}


Table 4: Research Question 4 - What could be done to reduce or eliminate stress?

\begin{tabular}{|c|c|c|c|}
\hline Question Items & Responses & Frequency of responses & Percentage (\%) \\
\hline Work redesign & $\begin{array}{l}\text { Strongly agreed } \\
\text { Agree } \\
\text { Disagree } \\
\text { Strongly Disagree } \\
\text { Total }\end{array}$ & $\begin{array}{l}45 \\
5 \\
0 \\
0 \\
\mathbf{5 0 \%}\end{array}$ & $\begin{array}{l}90 \% \\
10 \% \\
0 \% \\
0 \% \\
\mathbf{1 0 0 \%}\end{array}$ \\
\hline $\begin{array}{llll}\begin{array}{l}\text { Introduction of } \\
\text { training }\end{array} & \text { stress } & \text { management } \\
\end{array}$ & $\begin{array}{l}\text { Strongly agreed } \\
\text { Agree } \\
\text { Disagree } \\
\text { Strongly Disagree } \\
\text { Total }\end{array}$ & $\begin{array}{l}25 \\
10 \\
5 \\
10 \\
\mathbf{5 0 \%}\end{array}$ & $\begin{array}{l}50 \% \\
20 \% \\
10 \% \\
20 \% \\
\mathbf{1 0 0 \%}\end{array}$ \\
\hline Management development & $\begin{array}{l}\text { Strongly agreed } \\
\text { Agree } \\
\text { Disagree } \\
\text { Strongly Disagree } \\
\text { Total } \\
\end{array}$ & $\begin{array}{l}12 \\
11 \\
16 \\
11 \\
\mathbf{5 0 \%}\end{array}$ & $\begin{array}{l}24 \% \\
22 \% \\
32 \% \\
22 \% \\
\mathbf{1 0 0 \%} \\
\end{array}$ \\
\hline $\begin{array}{l}\text { Introduction of in-service or on-the-job } \\
\text { training for workers to improve their } \\
\text { human capacity. }\end{array}$ & $\begin{array}{l}\text { Strongly agreed } \\
\text { Agree } \\
\text { Disagree } \\
\text { Strongly Disagree } \\
\text { Total }\end{array}$ & $\begin{array}{l}30 \\
7 \\
10 \\
3 \\
\mathbf{5 0 \%}\end{array}$ & $\begin{array}{l}60 \% \\
14 \% \\
20 \% \\
6 \% \\
\mathbf{1 0 0 \%}\end{array}$ \\
\hline $\begin{array}{l}\text { Effort should be made to provide } \\
\text { working equipment and materials for } \\
\text { effective job performance }\end{array}$ & $\begin{array}{l}\text { Strongly agreed } \\
\text { Agree } \\
\text { Disagree } \\
\text { Strongly Disagree } \\
\text { Total } \\
\end{array}$ & $\begin{array}{l}25 \\
10 \\
5 \\
10 \\
\mathbf{5 0 \%} \\
\end{array}$ & $\begin{array}{l}50 \% \\
20 \% \\
10 \% \\
20 \% \\
\mathbf{1 0 0 \%} \\
\end{array}$ \\
\hline
\end{tabular}

Source: Field Survey 2020

\section{Discussion of Findings}

The results of research question one revealed that work overload, role ambiguity, lack of concentration, nondefined job specification and lack of effective equipment and materials needed to carry out task given are the causes and effect of stress on the performance of secretary. This finding is in accord with the findings of Ali (2006), who cited the common reason for stress that include work overloads, role ambiguity, underutilization of skills and many others.

The findings of research question two as analyzed in this chapter revealed the extend as to which stress affect the performance of secretary, as thus it was deduced from the respondent that stress affect the performance of the organization negatively such as: reducing concentration of secretary's at work, reduction in productivity, leading to job dissatisfaction, stress brought about rise in inferiority complex am secretary's and also it leads to unnecessary aggression among others. Similar study was conducted by Ali, (2005) and found out that, factors such as workload, role conflict and inadequate monetary rewards are the prime reasons for job stress that causes decrease in performance of employees.

The result of the findings of research question three indicated that stress affect organizational goals in different way such as leading to low morale among secretary's also it shows that stress causes poor working relationship among workers. Most of the respondents were also of the opinion that stress leads to reduction in productivity and also leads to high rate of employee's turnover in their organization. This study is in accord with the study of Mead (2015) who concluded in his study the impact of stress in job performance. He pointed out that there is negative impact of job stress on employee performance if stress is not managed effectively. Accordingly, too much stress negatively impacts the work performance of both the employees and the organization. Also in Omolara (2018), it was said that job dissatisfaction is known to lead to job stress, which in turn reduces the productivity.

The findings of the research question four as analyzed in this chapter shows possible measures to put in place in order to curb or eliminate stress from job environment such as work redesigned, introduction of management training, management development and also introduction of in-service or on-the-job training for workers to improve their services and lastly the findings also suggest that effort should be made to provide good working equipment and materials for effective job performance. This findings is accord with the Findings of Jenifer et al. (2006) who says stress management includes taking care of organizational issues like leadership, peer support, organizational culture and polices, work design and reporting arrangements as well as job analysis, staff selection and training to enhance role clarity such that there is a balance between the individual and his 
work environment. Effective systems for motivation and performance management are essential.

\section{Conclusion}

The aim of this study was to evaluate the effect of stress on productivity of secretaries at the Federal Polytechnic, Ede. The results from this study clearly show some factors causing stressful situation on the secretaries in the study area and the effect on their productivity.

\section{Recommendations}

Based on the findings of the research, it is recommend that the following, measured be put in place to help secretaries of the Federal Polytechnic, Ede manage and reduce stress at work.

Management should introduce stress management training program strategy at various unit in the Polytechnic.

- Management must conduct an analysis of the organizational culture and climate by assessing the reasons why employees think they are been over utilized.

- Supervisors and managers must assess the level of their subordinates knowledge and skills and whether they will meet their deadlines. They must agree on a performance contract, so that they can give employees with job maturity and control over their jobs.

- $\quad$ Time management training should be given to employees on continuous basis.

- Management should introduce stress management techniques at various units.

- Management should facilitate an employee's skill audit that will help to place employees that feel underutilized and also introduce good job specification to balance workflow among employees to help employees that feel over utilized.

\section{References}

Ali, A. (2005). Job Stress Causest. Othio: South Western Collage Publishing.

Blumenthal.I.(2016), Services SETA, Employee Assistance Conference Programme.2 (2), P5 -21.

Carrel, M.R. (2010), Human Resources Management. South Africa: Prentice Hall.

Dean, C. (2017). Stress and work Performance. HR Future. 2 (5).

Han, S. (2009). Professional secretaries experience. Journal of Management Research 8.(3).P123

Helena M. A. (2010).Stress at work: Linear and curvilinear effects of psychological-,job-,and organizationrelated factors: An exploratory study of Trinidad and Tobago. International journal of stress management, vol .13,No. 4,476-493

Henry, O. (2008). Occupational Stress in Organizations. Journal of Management Research 8.(3).P123-135

Jamal, M.(2007). Job stress and job performance controversy revisited: An empirical examination in two countries. International journal of stress management, vol .14, No. 2,175-187

Jenifer M. (2006). Human Resource Management an Experimental Approach $2^{\text {nd }}$ Ed. New Jersey. Prentice Hall.

Jennifer M. (2016). Positive and negative affective outcomes of occupational stress .New Zealand journal of Psychology Vol 35, No. 2.

John Micheal (2007). Human Resource Management. Othio: South Western Collage Publishing.

Mathis, R.I. \& Jackson J.H.(2014) Human Resource Management. Othio: South Western Collage Publishing

McGowanJ., (2006).Positive and Negative Affective Outcomes of Occupational Stress. Massey University, Auckland .New Zealand Journal of Psychology Vol.35, No. 2.

Mead, A. (2015), Tackle Work Place Stress to Improve Productivity, Reduce Absenteeism, Staff Leader, 15(2)

Omolara, B.E (2018) Influence of work related stress on organizational commitment Olabisi Onabanjo University Ago Iwoye Ogun state Nigeria, EABR \& TLC Conferences Proceedings, Rothenberg, Germany.

Pestonjee,D. M. (1999) Studies in stress and its management. Oxford \& IBH Publishing Co. Pvt. Ltd., Stress and mental workload: A conceptual synthesis, pp 48-52. 